\title{
Carbamate complexation by urea-based receptors: studies in solution and the solid state
}

\author{
Peter. R. Edwards, Jennifer. R. Hiscock, Philip. A. Gale*, and Mark. E. Light \\ Received (in XXXX, XXX) Xth XXXXXX 20XX, Accepted XXth XXXXXXX 20XX \\ ${ }_{5}$ First published on the web $X X$ th $X X X X X 20 X X$ \\ DOI: 10.1039/b0000000x
}

The interactions of a series of urea based neutral hydrogen bond donor anion receptors have been investigated with i) alkylcarbamate anions formed by the reaction of carbon dioxide with primary aliphatic amines and ii) the zwitterionic species formed by the reaction of carbon dioxide with 10 1,4,5,6-tetrahydropyrimidine. Significant downfield chemical shift changes were observed for the urea NH protons in many cases, consistent with host:anion hydrogen bonding interactions, and thus stabilisation of the carbon dioxide bound species. In the case of the alkylammoniumalkylcarbamate salts, this represents successful competition with electrostatic interactions between the alkylcarbamate and alkylammonium components of the salt. A synchrotron structure of a

15 ternary complex formed by an amide appended diindolylurea, the ammonium carbamate salt formed by 1,3-diaminopropane and $\mathrm{CO}_{2}$ and 18-crown- 6 was elucidated and shows the carbamate group bound by six hydrogen bonds (accepting five and donating one) to the functionalised diindolylurea.

\section{Introduction}

20 The emission of the green-house gas carbon dioxide has increased greatly over the past 200 years as a result of the increased use of fossil fuels ${ }^{1}$. This has significantly raised the atmospheric concentration of carbon dioxide, which is anticipated to have widespread detrimental effects on the 25 global climate ${ }^{2}$. Much recent work has focused on the fixation $^{3}$, activation or stabilisation ${ }^{4}$ of carbon dioxide, with the aim of either removing excess carbon dioxide from the gas phase/atmosphere ${ }^{5}$, or using it as a green chemical feedstock for the synthesis of specific chemical intermediates ${ }^{6}$.

30

The use of primary amines as carbon dioxide "scrubbers" is extensive in industry due to their wide availability, low cost and the high stability of the alkylammonium-alkylcarbamate (AAAC) salt ${ }^{7}$. It is also possible to release the carbon dioxide 35 by moderate temperature elevation ${ }^{8}$. Weiss and co-workers have previously shown that the two components of the salt exchange carbon dioxide and a proton very rapidly on the NMR timescale, (Scheme 1). ${ }^{9}$

a
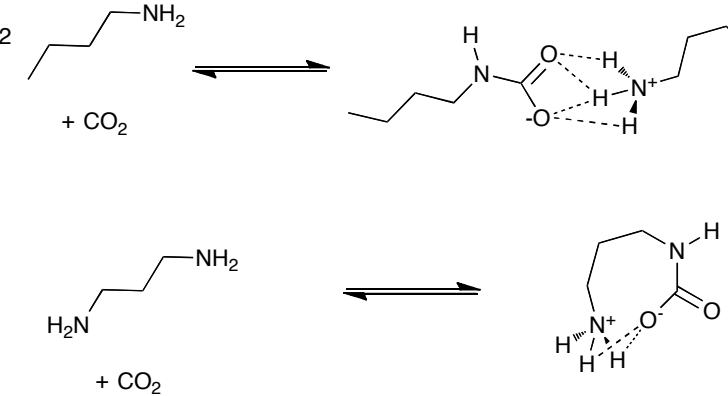

Cyclic amidines such as 1,4,5,6-tetrahydropyrimidine (THP) have also attracted much attention as carbon dioxide fixation ${ }_{45}$ agents, due to their charge neutral products ${ }^{10}$. The adduct formed by reaction of THP with carbon dioxide (THP-CO $\left.\mathrm{CO}_{2}\right)$, is zwitterionic, and can be thought of as analogous to the alkylcarbamate component of the AAAC salt, (Scheme 2).

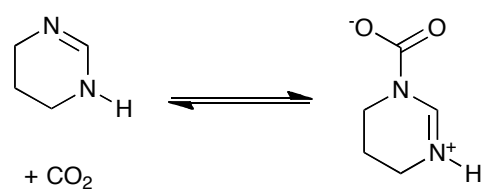

Scheme 2. Formation of THP- $\mathrm{CO}_{2}$ by reaction of $1,4,5,6-$ tetrahydropyrimidine with carbon dioxide.

${ }_{55} \mathrm{We}$ have recently reported the anion binding affinities of receptors 5 - 8 in $\mathrm{H}_{2} \mathrm{O}$ :DMSO- $d_{6}$ mixtures ${ }^{11}$. Receptor $\mathbf{6}$ for example, binds acetate with a stability constant $>10^{4} \mathrm{M}^{-1}$ in $0.5 \% \mathrm{H}_{2} \mathrm{O}$ :DMSO- $d_{6}$. We hypothesised that these receptors and receptors $4^{12}$ and $9^{11 \mathrm{~d}}$, would be capable of binding and ${ }_{60}$ hence stabilising the alkylcarbamate anion component of AAAC salts and THP- $\mathrm{CO}_{2}$, via hydrogen bond formation in organic solution. Proton NMR experiments in DMSO- $d_{6}$ were used to assess the interactions. Three other simple ureas, $\mathbf{1}^{13}$, $\mathbf{2}^{14}$ and $\mathbf{3}^{15}$ were prepared according to literature procedures 65 and have been studied for comparison. Aspects of our work on AAAC salt complexation have been communicated previously. $^{12}$

40 Scheme 1. Formation of AAAC salts by reaction of a) n-butylamine and b) 1,3-diaminopropane, with carbon dioxide 
<smiles>CCCCCCNC(=O)NCCCC</smiles><smiles>CCCCNC(=O)Nc1ccccc1</smiles><smiles>O=C(Nc1ccccc1)Nc1ccccc1</smiles><smiles>O=C(Nc1ccccc1)Nc1cccc2cc[nH]c12</smiles>

4<smiles>O=C(Nc1ccccc1)Nc1cccc2c1[nH]c1ccccc12</smiles>

5<smiles>O=C(Nc1cccc2cc[nH]c12)Nc1cccc2cc[nH]c12</smiles><smiles>O=C(Nc1cccc2cc[nH]c12)Nc1cccc2c1[nH]c1ccccc12</smiles>

7<smiles>O=C(Nc1cccc2c1[nH]c1ccccc12)Nc1cccc2c1[nH]c1ccccc12</smiles>

8<smiles>CCCCNC(=O)c1cc2cccc(NC(=O)Nc3cccc4cc(C(=O)NCCCC)[nH]c34)c2[nH]1</smiles>

When AAAC salts are formed in solution with a suitable receptor, it is anticipated that the anionic component of the 5 salt will form hydrogen bonding interactions with the receptor. We hypothesised that addition of 18-crown-6 would result in complex formation with the alkylammonium cation of the AAAC salt ${ }^{16}$ and hence reduce the degree of ion-pairing in solution between the ammonum and carbamate groups 10 (Scheme 3).
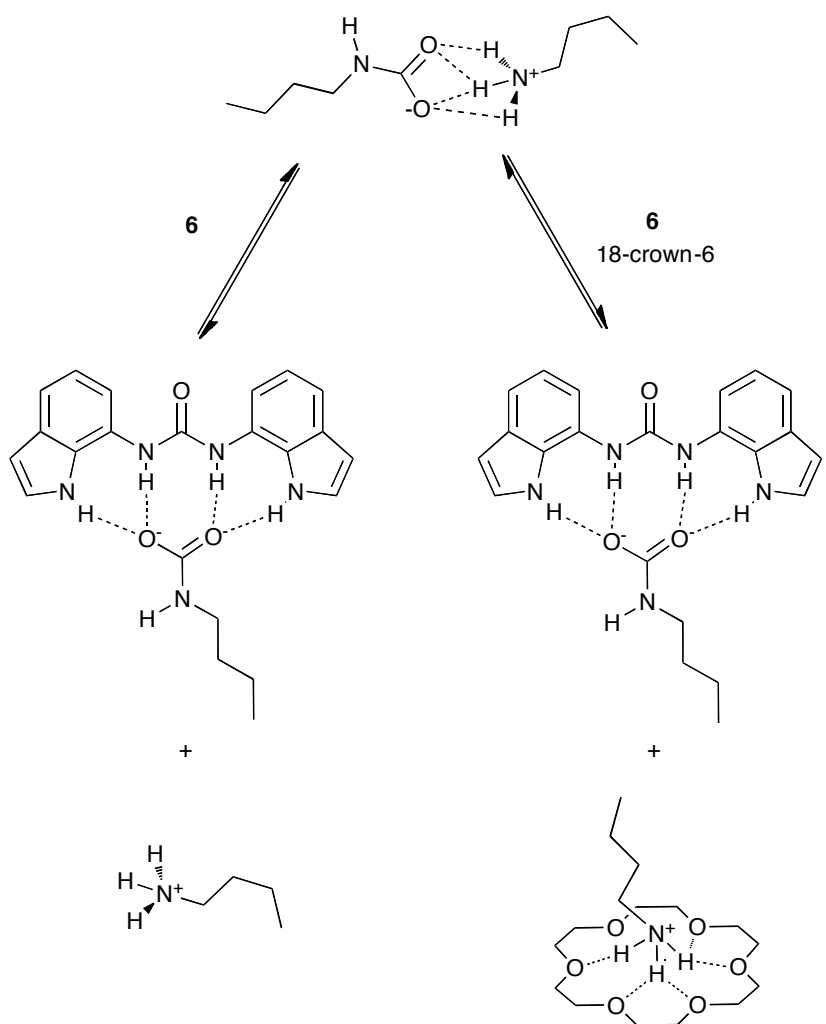

Scheme 3 Expected binding modes between $\mathbf{6}$ and AAAC salts in the presence and absence of 18-crown- 6 .

In the case of THP-CO $\mathrm{CO}_{2}$ there is expected to be a lower degree 15 of ion-pairing in solution as the adduct is a neutral zwitterion. This will lead to an enhanced interaction between the zwitterion and urea-based receptor and hence stronger binding to the receptors than was observed with the AAAC salts, (Scheme 4).

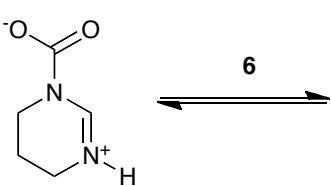

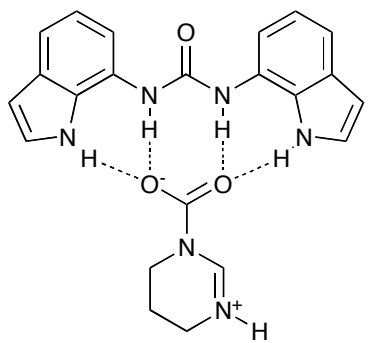

Scheme 4. Expected binding mode between 6 and THP-CO 


\section{Results and discussion}

Initially, we attempted to measure stability constants between receptors 1 - 9 and the activated $\mathrm{CO}_{2}$ species using ${ }^{1} \mathrm{H}$ NMR titration techniques. However, we found that the data obtained 5 could not be reproduced reliably. This is presumably due to the loss of carbon dioxide from solution over the timescale of the titration, leaving unknown concentrations of the AAAC or THP- $\mathrm{CO}_{2}$ adduct in solution.

We have observed that when one equivalent of AAAC salt 10 or THP- $\mathrm{CO}_{2}$ adduct is formed in solution in the presence of a receptor, carbon dioxide is not readily lost from solution as evidenced by the high reproducibility of the chemical shift of the urea NH protons of $\mathbf{1}$ - 9 in the presence of AAAC salts or THP- $\mathrm{CO}_{2}$. We have observed that the solutions produce 15 identical spectra $24 \mathrm{~h}$ after preparation.

We looked at the corelation between chemical shift upon addition of one equivalent of guest and stability constant for titrations of the receptors with tetrabutylammonium benzoate which had been conducted previously ${ }^{11}$ and also conducted 20 new titrations with receptors $\mathbf{1}, \mathbf{2}$ and $\mathbf{4}$ and tetrabutylammonium benzoate. The results (shown in the ESI) show an average shift of $1.2 \mathrm{ppm}$ for the urea protons of compounds 1, $\mathbf{2}$ and $\mathbf{3}$ which have stability constants between $17 \mathrm{M}^{-1}$ and $674 \mathrm{M}^{-1}, 1.75 \mathrm{ppm}$ for compounds $\mathbf{5}, 7$ and 8 25 which have stability constants between 3400 and $5880 \mathrm{M}^{-1}$, and $2.4 \mathrm{ppm}$ for compounds $\mathbf{4}, \mathbf{6}$ and 9 with stability constants $>10^{4} \mathrm{M}^{-1}$. It may be that the different families of compounds here (e.g. simple ureas, ureas with one extra hydrogen bond donor, ureas with two extra hydrogen bond 30 donors and compound 9) have different binding modes with the carbamate guests. However, the correspondence between chemical shift of the urea $\mathrm{NH}$ groups and $K_{a}$ observed with the compounds in the presence of one equivalent of benzoate is evidence that leads us to expect at least some degree of 35 corelation between the chemical shift of the urea $\mathrm{NH}$ protons in the absence and presence of one equivalent of carbamate and the stability constant with carbamate. Hence we observed the chemical shift change of the urea NH protons between the unbound receptor and the bound receptor, obtaining an 40 indication of the strength of the binding between the series of structurally related receptors and the guest.

A series of solutions were prepared in DMSO- $d_{6}$ containing $1 \mathrm{mM}$ of receptor $\mathbf{1}$ - 9 and either, a) 2eq. n-butylamine, b) 1eq. 1,3-diaminopropane, c) 2eq. n-butylamine +1 eq. 18 45 crown-6, d) 1eq. 1,3-diaminopropane +1 eq. 18-crown-6, or e) 1eq. THP. The compounds were dissolved and subjected to bubbling of carbon dioxide for 3 minutes. Mean chemical shift changes of three repeats are presented, (Tables 1-5).

Downfield chemical shift changes were observed for the 50 urea NH proton resonances for many receptor:guest combinations. The smallest magnitude chemical shift changes were observed with the AAAC salts in the absence of 18crown-6. Slightly larger chemical shift changes were observed with the AAAC salts in the presence of 18-crown-6, whilst ${ }_{55}$ larger chemical shift changes were observed in the presence of the THP- $\mathrm{CO}_{2}$ adduct. Receptors $\mathbf{1}$ - $\mathbf{3}$ contain two hydrogen bond donors and showed the smallest chemical shift changes with each AAAC salt and the THP- $\mathrm{CO}_{2}$ adduct. Receptors 4 -
5, which contain three hydrogen bond donors, have slightly ${ }_{60}$ larger chemical shift changes, whilst receptors $\mathbf{6}-\mathbf{8}$, which contain four hydrogen bond donors, have the largest chemical shift changes of this series of receptors. Chemical shift changes could not be obtained for receptor 9 with either AAAC salt, in either the presence or absence of 18-crown-6, ${ }_{65}$ due to resonance broadening in the ${ }^{1} \mathrm{H}$ NMR spectrum. With THP- $\mathrm{CO}_{2}$, a moderate chemical shift change was observed.

Table 1 Mean chemical shift changes/ppm for one or two urea NH groups labelled as downfield or upfield (with errors/\%) for 1-8 in the presence of 70 2eq. n-butylamine, exposed to a stream of carbon dioxide for three minutes.

$\begin{array}{ll}\text { Urea NH } & \text { Urea NH } \\ \text { (downfield resonance) } & \text { (upfield resonance) }\end{array}$

\begin{tabular}{|c|c|c|}
\hline 1 & 0 & 0 \\
\hline 2 & 0 & 0 \\
\hline 3 & $0.11 \quad$ (13) & \\
\hline 4 & $0.26 \quad(6)$ & 0.28 \\
\hline 5 & $0.27 \quad(13)$ & 0.30 \\
\hline 6 & $0.71 \quad(7)$ & \\
\hline 7 & $0.67 \quad(10)$ & 0.68 \\
\hline 8 & $0.63 \quad(5)$ & \\
\hline
\end{tabular}

Table 2 Mean chemical shift changes/ppm for one or two urea NH groups 75 labelled as downfield or upfield (with errors/\%) for 1-8 in the presence of 1eq. 1,3-diaminopropane, exposed to a stream of carbon dioxide for three minutes.

$\begin{array}{ll}\begin{array}{l}\text { Urea } \mathrm{NH} \\ \text { (downfield resonance) }\end{array} & \begin{array}{l}\text { Urea NH } \\ \text { (upfield resonance) }\end{array}\end{array}$

$\begin{array}{lllll}\mathbf{1} & 0 & & 0 & \\ \mathbf{2} & 0 & & 0 & \\ \mathbf{3} & 0.08 & (23) & & \\ \mathbf{4} & 0.28 & (14) & 0.30 & (15) \\ \mathbf{5} & 0.37 & (9) & 0.42 & (10) \\ \mathbf{6} & 0.70 & (10) & & \\ \mathbf{7} & 0.50 & (7) & 0.51 & (6) \\ \mathbf{8} & 0.56 & (6) & \end{array}$

80 Table 3 Mean chemical shift changes/ppm for one or two urea NH groups labelled as downfield or upfield (with errors/\%) for 1-8 in the presence of 2eq. n-butylamine and 1eq. 18 -crown- 6 exposed to a stream of carbon dioxide for three minutes.

$\begin{array}{ll}\text { Urea NH } & \text { Urea NH } \\ \text { (downfield resonance) } & \text { (upfield resonance) }\end{array}$

$\begin{array}{lllll}\mathbf{1} & 0 & & 0 & \\ \mathbf{2} & 0 & & 0 & \\ \mathbf{3} & 0.10 & (6) & & \\ \mathbf{4} & 0.34 & (15) & 0.37 & (7) \\ \mathbf{5} & 0.36 & (13) & 0.39 & (13) \\ \mathbf{6} & 0.45 & (1) & & \\ \mathbf{7} & 0.66 & (1) & 0.66 & (1) \\ \mathbf{8} & 1.18 & (3) & \end{array}$

85 
Table 4 Mean chemical shift changes/ppm for one or two urea NH groups labelled as downfield or upfield (with errors/\%) for 1-8 in the presence of 1eq. 1,3-diaminopropane and 1eq. 18-crown-6, exposed to a stream of carbon dioxide for three minutes.

$\begin{array}{ll}\begin{array}{l}\text { Urea NH } \\ \text { (downfield resonance) }\end{array} & \begin{array}{l}\text { Urea NH } \\ \text { (upfield resonance) }\end{array}\end{array}$

$\begin{array}{llllll}\mathbf{1} & 0 & & 0 & \\ \mathbf{2} & 0 & & 0 & \\ \mathbf{3} & 0.15 & (6) & & \\ \mathbf{4} & 0.43 & (4) & 0.46 & (5) \\ \mathbf{5} & 0.40 & (2) & 0.45 & (2) \\ \mathbf{6} & 0.59 & (6) & & \\ \mathbf{7} & 0.78 & (5) & 0.78 & (5) \\ \mathbf{8} & 0.77 & (10) & & \end{array}$

5 Chemical shift changes presented are the means of three repeats.

Table 5 Mean chemical shift changes/ppm for one or two urea NH groups labelled as downfield or upfield for 1-9 in the presence of 1eq. 1,4,5,6tetrahydropyrimidine, exposed to a stream of carbon dioxide for three 10 minutes.

\begin{tabular}{|c|c|}
\hline $\begin{array}{l}\text { Urea NH } \\
\text { (downfield resonance) }\end{array}$ & $\begin{array}{l}\text { Urea NH } \\
\text { (upfield resonance) }\end{array}$ \\
\hline $0.03 \quad(37)$ & $0.03 \quad$ (37) \\
\hline $0.22 \quad(13)$ & 0.23 (13) \\
\hline $0.75 \quad$ (4) & \\
\hline $1.09 \quad(12)$ & $1.32(10)$ \\
\hline $1.06 \quad$ (4) & 1.25 (4) \\
\hline $1.17 \quad$ (5) & \\
\hline $1.31 \quad$ (4) & $1.34 \quad(4)$ \\
\hline $1.42 \quad$ (3) & \\
\hline
\end{tabular}

0.87 (6)

Chemical shift changes presented are the means of three repeats.

\section{Alkylammonium:alkylcarbamate salts}

The chemical shift changes of the urea $\mathrm{NH}$ protons with 15 AAAC salts are relatively small compared to those observed with tetrabutylammonium oxo-anion salts or $\mathrm{THP}-\mathrm{CO}_{2}$. We propose that this can be attributed to non-innocent nature of the ammonium cation, resulting in a large proportion of the alkylcarbamate anion bound via hydrogen bonds and

20 electrostatic interactions to the alkylammonium cation. The neutral receptors compete with the ion-pairing interaction to different extents, dependent on their relative affinities for carbamate anions.

In the absence or presence of 18-crown-6 no chemical shift 25 changes are observed for receptors 1 or $\mathbf{2}$ (Figures 1 and 2). This is attributed to their poor oxo-anion binding affinities in the competitive solvent, DMSO- $d_{6}$. With receptor 3, (which binds benzoate with $\mathrm{K}_{\mathrm{a}}=674 \mathrm{M}^{-1}$ in $0.5 \% \mathrm{H}_{2} \mathrm{O}$ :DMSO- $\left.d_{6}\right)$, ${ }^{11 \mathrm{c}}$ there are chemical shift changes of around $0.08-0.15 \mathrm{ppm}$ for 30 the urea $\mathrm{NH}$ protons (Figures 1 and 2). With receptors 4 and 5 , (5 binds benzoate with $\mathrm{K}_{\mathrm{a}}=3,420 \mathrm{M}^{-1}$ in $0.5 \% \mathrm{H}_{2} \mathrm{O}$ :DMSO$\left.d_{6}\right)^{11 \mathrm{~b}}$ there are larger chemical shift changes of around $0.26-$ $0.45 \mathrm{ppm}$ (Figures 1 and 2). With receptors $\mathbf{6}, 7$, and $\mathbf{8}$ (which bind benzoate $5,880 \mathrm{M}^{-1}<\mathrm{K}_{\mathrm{a}}$ in $0.5 \% \mathrm{H}_{2} \mathrm{O}$ :[D6]DMSO) ${ }^{11}$, the 35 chemical shift changes are all larger, around $0.45-1.18 \mathrm{ppm}$ (Figures 1 and 2).

It can be seen from this data, that the larger the stability constant for tetrabutylammonium benzoate complexation, the larger the chemical shift changes with alkylcarbamate anions. ${ }_{40}$ Whilst care should be taken when attempting to draw comparisons between chemical shift changes and binding affinities, analogy with our previous work suggests that receptors $\mathbf{6}-\mathbf{8}$ will bind AAAC salts most strongly. It is reasonable to conclude that when looking across this series of 45 structurally related receptors when following a similar urea NH group, that a high affinity receptor should exhibit larger chemical shift changes than a low affinity receptor.

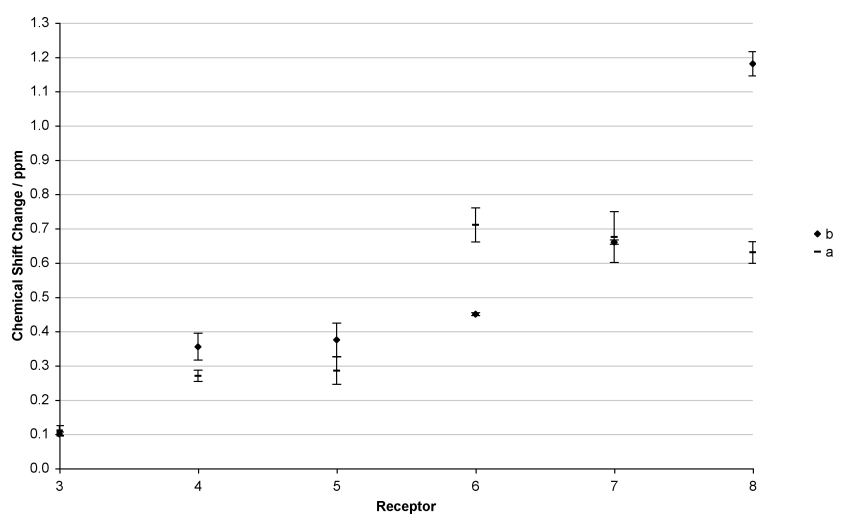

50 Fig. 1 Chemical shift changes of one or two urea NH proton(s) (averaged with errors) observed for receptors $\mathbf{3}$ - 8 upon addition of a) 2eq. nbutylamine bubbled with carbon dioxide for three minutes, and b) 2eq. nbutylamine +1 eq. 18 -crown- 6 , bubbled with carbon dioxide for three minutes.

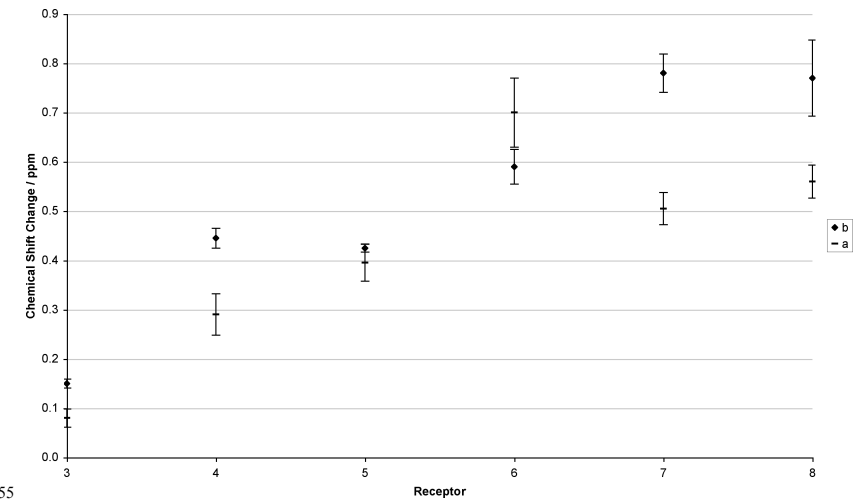

Fig. 2 Chemical shift changes of one or two urea NH proton(s) (averaged with errors) observed for receptors 3 - 8 upon addition of a) 1eq. 1,3diaminopropane bubbled with carbon dioxide for three minutes, and $b$ ) 1eq. 1,3-diaminopropane +1 eq. 18 -crown- 6 , bubbled with carbon dioxide 60 for three minutes.

The addition of 18-crown-6 has the effect of increasing the chemical shift changes for the majority of the receptors compared to absence of 18-crown-6 and is particularly evident 65 with receptor 8 (Figure 1). This observation appears to confirm the hypothesis that addition of 18-crown-6 will reduce the degree of ion-pairing in solution between the ammonium cations and carbamate anions.

However, interestingly, the chemical shift change of 70 receptor 6 decreases upon addition of 18-crown-6. This leads to a trend where the chemical shift changes are related to the number of hydrogen bond donors and acidity of the indole or 
carbazole pendant groups (Figures 1 and 2). Both of these increase from receptor $\mathbf{1}$ to receptor $\mathbf{8},\left(\mathrm{pK}_{\mathrm{a}}\right.$ indole $\mathrm{NH}=21.0$ in DMSO, $\mathrm{pK}_{\mathrm{a}}$ carbazole $\mathrm{NH}=19.9$ in $\left.\mathrm{DMSO}\right)^{17}$, causing increasingly larger chemical shift changes. It is not yet clear 5 why compound 6 undergoes a larger chemical shift in the absence of 18-crown- 6 anions than more acidic compounds 7 and 8. The decrease in chemical shift of the urea protons of compound 6 upon addition of 18-crown- 6 brings the chemical shift into line with what would be expected considering the 10 acidity of the receptor relative to the other receptors studied.

\section{THP-CO $\mathrm{O}_{2}$ adduct}

The THP- $\mathrm{CO}_{2}$ adduct can be thought of as a zwitterionic AAAC analogue. The species is neutral and therefore there is 15 less scope for ion pairing in solution. It is therefore expected that THP- $-\mathrm{CO}_{2}$ will cause greater chemical shift changes of the urea $\mathrm{NH}$ protons of receptors $\mathbf{1}-\mathbf{8}$, than AAAC salts due to the lower degree of ion-pairing. It was found that $\mathrm{THP}-\mathrm{CO}_{2}$ causes much larger chemical shift changes than the AAAC 20 alkylcarbamate anions. THP- $\mathrm{CO}_{2}$ causes a small chemical shift change with receptor $\mathbf{1}$, and causes chemical shift changes of 0.22 and $0.23 \mathrm{ppm}$ for the two urea NH protons of receptor 2 (Figure 3 ). The chemical shift changes of the urea $\mathrm{NH}$ protons then increase from $0.75 \mathrm{ppm}(3)$, to between 1.06 ${ }_{25} 1.42 \mathrm{ppm}(4-8)$ (Figure 3). As with AAAC salts in the presence of 18 -crown-6, receptors 7 and $\mathbf{8}$ have the largest chemical shift changes, (Figure 3 ). The urea $\mathrm{NH}$ protons of receptor 9 undergo smaller chemical shift changes than those in compounds $\mathbf{6}-\mathbf{8}$ with THP-CO 2 under identical conditions. 30

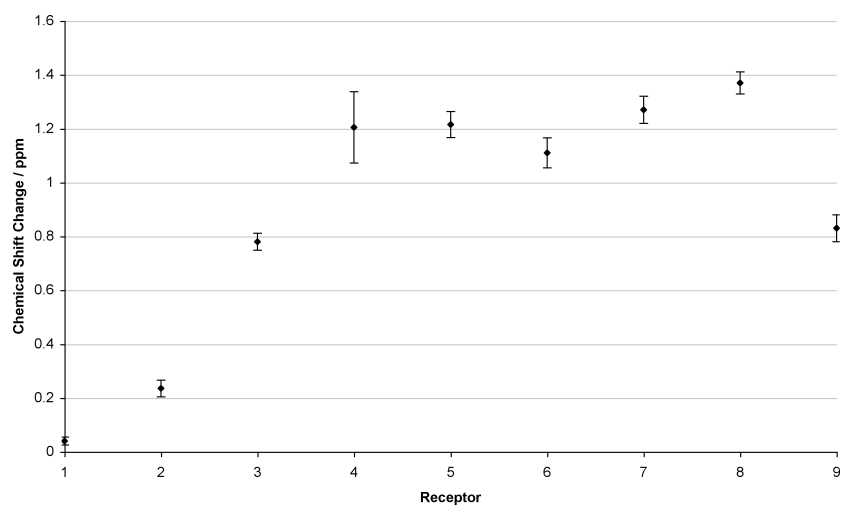

Fig 3. Chemical shift changes of one or two urea NH proton(s) (averaged with errors) observed for receptors 1 - 9 in the presence of 1eq. 1,4,5,6-

\section{Solid state studies}

Crystals of a 1:1:1 ternary complex of 9, 18-crown-6 and the AAAC salt formed from carbon dioxide and 1,3diaminopropane were obtained by slow evaporation of a 40 DMSO solution of the complex. The structure (Figure 4) shows the zwitterion bound to both receptor 9 (complexing the carbamate group by donating five hydrogen bonds and accepting one) and 18-crown-6 (binding the ammonium group). There are two such complexes in the asymmetric unit.

${ }_{45}$ The amide groups in receptor $\mathbf{9}$ are oriented such that one $\mathrm{NH}$ is oriented into the binding site whilst the other amide is oriented such that the $\mathrm{C}=\mathrm{O}$ groups is oriented into the binding site. This allows one amide to donate a hydrogen bond to a carbamate oxygen whilst the other amide $\mathrm{C}=\mathrm{O}$ can accept a 50 hydrogen bond from the carbamate $\mathrm{NH}$ group. The structure of the complex is also shown schematically (Figure 5). Please see the supplementary information for additional views and a table of hydrogen bonding interactions present in this complex.

55

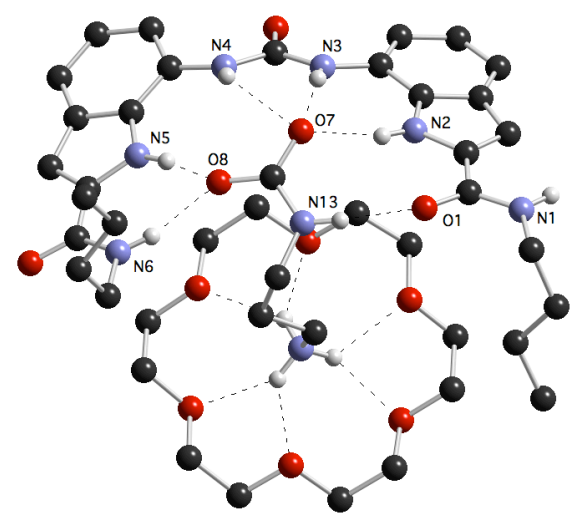

Fig. $4 \mathrm{~A}$ view of one of the two complexes in the asymmetric unit of the ternary complex of the AAAC salt formed by 1,3-diaminopropane and carbon dioxide bound to receptor 9 and 18-crown-6. Solvent and non60 acidic hydrogen atoms have been omitted for clarity.

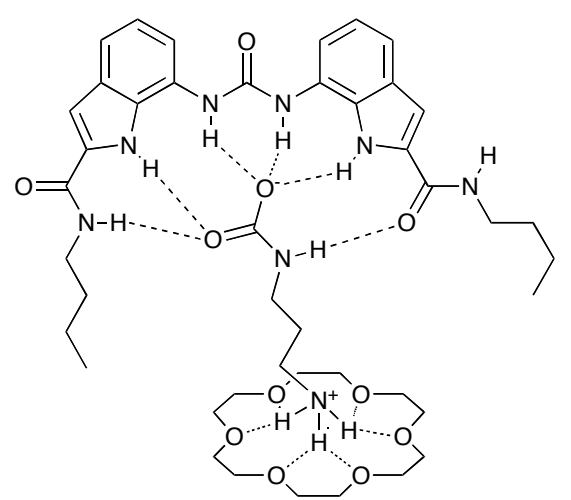

Fig. 5 Diagram of one of the two complexes in the asymmetric unit of the 65 ternary complex of the AAAC salt formed by 1,3-diaminopropane and carbon dioxide bound to receptor 9 and 18-crown-6.

\section{Conclusions}

We have shown that it is possible to bind the alkylcarbamate 70 portion of alkylammonium alkylcarbamate salts in solution using a series of urea-based receptors under competitive conditions. An indication of the relative strengths of these interactions can be gained by considering the magnitude of the 
chemical shift changes of the urea $\mathrm{NH}$ protons that are involved in the binding. We have also demonstrated that it is possible to stabilise the alkylammonium cation with a crown ether, which in most cases leads to enhanced hydrogen 5 bonding between the neutral carbamate receptor and the alkylcarbamate anion. Decreasing the degree of ion-pairing in solution by using the zwitterionic species THP-CO $\mathrm{CO}_{2}$ instead of alkylammonium alkylcarbamate salts causes significantly larger chemical shift changes, consistent with a greater 10 effective concentration of anionic species in solution. The crystal structure of the AAAC salt bound to receptor 9 and 18crown-6 illustrates how a combination of anion and cation receptors can be employed to complex species formed from the reaction of diamines and carbon dioxide.

\section{${ }_{15}$ Acknowledgements}

PAG thanks the EPSRC (C-Cycle) for funding. The authors would like to thank the EPSRC for funding and Professor W. Clegg and members of the National Crystallography Service for data collection at Diamond. ${ }^{18}$

\section{${ }_{20}$ Notes and references}

a School of Chemistry, University of Southampton, Southampton, UK. Fax: 442380 80596805; E-mail: philip.gale@soton.ac.uk

$\dagger$ Electronic Supplementary Information (ESI) available: [Representative ${ }^{1} \mathrm{H}$ NMR spectra for each combination of receptor:guest. Additional views 25 of crystal structure, and table of hydrogen bonding interactions.] See DOI: $10.1039 / \mathrm{b} 000000 \mathrm{x} /$

\$ Crystallographic data were collected at Diamond beamline I19 using a Rigaku Saturn 724+ detector on a Crystal Logics diffractometer. Crystal data for $9\left[\mathrm{H}_{3} \mathrm{~N}^{+}\left(\mathrm{CH}_{2}\right)_{3} \mathrm{NHCO}_{2}{ }^{-}\right]\left[18\right.$-crown-6]: $2\left(\mathrm{C}_{27} \mathrm{H}_{32} \mathrm{~N}_{6} \mathrm{O}_{3}\right)$

$302\left(\mathrm{C}_{12} \mathrm{H}_{24} \mathrm{O}_{6}\right) 2\left(\mathrm{C}_{4} \mathrm{H}_{10} \mathrm{~N}_{2} \mathrm{O}_{2}\right) \quad 0.5\left(\mathrm{C}_{2} \mathrm{H}_{6} \mathrm{OS}\right), M=1781.14$, Triclinic, $a=$ 12.626(7), $b=14.165(9), c=27.564(17) \AA, \alpha=84.204(10)^{\circ}, \beta=$ $77.246(8)^{\circ}, \gamma=72.121(9)^{\circ}, U=4573(5) \AA^{3}, T=120(2) \mathrm{K}$, space group $P \overline{1}, Z=2, \mu$ (synchrotron) $=0.105 \mathrm{~mm}^{-1}, 34055$ reflections measured, 14794 unique reflections $\left(R_{\text {int }}=0.0680\right)$. The final $R_{l}$ values were 0.0649

${ }_{35}(I>2 \sigma(I))$. The final $w R\left(F_{2}\right)$ values were $0.1813(I>2 \sigma(I))$. The final $R_{I}$ values were 0.0854 (all data). The final $w R\left(F_{2}\right)$ values were 0.1936 (all data).

1. M. Aresta and A. Dibendetto, Dalton. Trans. 2007, 2975.

2. The Third Assesment Report of the Intergovernmental Panel on Climate Change, B. Mertz, O. Davidson, R. Sware and J. Pan, Cambridge University Press: Cambridge, 2001.

3. (a) R. Banerjee, A. Phan, B. Wang, C. Knobler, H. Furukawa, M. O'Keeffe and O.M. Yaghi, Science, 2008, 319, 939; (b) Z. Chen, H-S. Song, M. Portillo, C. Jim Lim, J.R. Grace and E.J. 45 Anthony, Energy. Fuels., 2009, 23, 1437; (c) X-X. Zhao, X-L. $\mathrm{Zu}, \mathrm{S}-\mathrm{B}$, Sun, L-L Zhang and X-Q Liu, Energy Fuels., 2009, 23, 1534; (d) C. Zhao, X. Chen and Y. Liu. Energy Fuels., 2009, 23, 1766; (e) J.L. Atwood, L.J. Barbour and J. Jerga, Angew. Chem. Int. Ed., 2004, 43, 2948; (f) S.J. Dalgarno, J. Tian, J.E. Warren, T.E. Clark, M. Makha, C.L. Raston and J.L. Atwood, Chem. Commun., 2007, 4848; (g) H. Zhou, W-Z. Ziang, Y-M. Wang, J-P. Qu and X-B. Lu, Macromolecules, 2009, DOI: 10.1021/ma901109j

4. (a) B. Verdejo, S. Blasco, J. Gonzalez, E. García-España, P. Gavina, S. Tatay, A. Domenech, M.T. Domenech-Carbo, H.R. Jimenez and C. Soriano, Eur. J. Inorg. Chem., 2008, 84; (b) E. García-España, P. Gavina, J. Latorre, C. Soriano and B. Verdejo, J. Am. Chem. Soc., 2004, 126, 5082; (c) S.J. Brooks, P.A. Gale and M.E. Light, Chem. Commun., 2006, 4344.

5. (a) Z. Liang, M. Marshall and A.L. Chaffee, Energ. Fuel. 2009, 23, 2785; (b) Z.Q. Wang and S.M Cohen, J. Am. Chem. Soc., 2009, 129, 12368; (c) O.M. Yaghi, M. O'Keeffe, N.W.
Ockwig, H.K Chae, M. Eddaoudi and J. Kim, Nature, 2003, 423, 705; (d) B. Arstad, H. Fjellvag, K.O. Kongshuang, O. Swang and R. Blom, Adsorption, 2008, 14, 755 (e) S. Couck, J.F.M. Denayer, G.V. Baron, T. Rémy, J. Gascon, and F. Kapteijn, J. Am. Chem. Soc., 2009, 131, 6326 (f) B. Mu, F. Li, and K.S. Walton, Chem. Commun., 2009, 2493 (g) L. Natrajan, J Pécaut and M. Mazzanti, Dalton. Trans., 2006, 1002; (h) S.J. Brooks, P.A. Gale and M.E. Light Chem. Commun. 2006, 4344; (i) J.A. Tossell, Inorg. Chem. 2009, 48, 7105; (j) S.J. Brooks, S.E. García-Garrido, M.E. Light, P.A. Cole and P.A. Gale, Chem. Eur. J. 2007, 13, 3320-3329.

6. (a) X. Zheng, Z. Luo, L Zhang and J-P. Cheng, Green Chem., 2009, 11, 455; (b) Y.O. Sharma and M.S. Degani, Green Chem., 11, 526; (c) J. Song, Z. Zhang, S. Hu, T. Wu, T. Jiang, and B. Han, Green Chem. 2009, 11, 1031.

7. (a) A. Diaf, L.J. Garcia and E.J. Beckmann, J. Appl. Polym. Sci., 1994, 53, 956; (b) A. Diaf, R. M. Enick, and E.J. Beckamnn, J. Appl. Polym. Sci., 1993, 50, 835; (c) G. Sartori, W.S. Ho and D.W. Savage, Separ. Purif. Meth. 1987, 16, 171.

8. N. Belman, J.N. Israelachvili, Y. Li, C.R. Safinya, J. Bernstein and Y. Golan, J. Am. Chem. Soc., 2009, 131, 9107.

9. M. George and R.G Weiss, Langmuir, 2003, 19, 8168 .

10. (a) T. Endo, D. Nagai, H. Yamaguchi and B. Ochiai, Macromolecules. 2004, 37, 2007.(b)T. Seçin, B. Alici, E. Çetinkaya and I. Özdemir, J. Polym. Sci. A1., 1997, 35, 2411.

11. (a) C. Caltagirone, J.R. Hiscock, M.B. Hursthouse, M.E. Light and P.A. Gale, Chem. Eur. J. 2008, 14, 10236; (b) J.R. Hiscock, C. Caltagirone, M.E. Light, M.B. Hursthouse and P.A. Gale, Org. Biomol. Chem., 2009, 7, 1781; (c) C. Caltagirone, P.A. Gale, J.R. Hiscock, S.J. Brooks, M.B. Hursthouse and M.E. Light, Chem. Commun., 2008, 3007; (d) P.A. Gale, J.R. Hiscock, S.J. Moore, C. Caltagirone, M.B. Hursthouse and M.E. Light, Chem. Asian J. DOI: 10.1002/asia.200900230. For our other work on indole containing anion receptors see: (e) G.W. Bates, Triyanti, M.E. Light, M. Albrecht and P.A. Gale, J. Org. Chem. 2007, 72, 8921; (f) C. Caltagirone, P.A. Gale, J.R. Hiscock, M.B. Hursthouse, M.E. Light and G.J. Tizzard, Supramolecular Chem., 2009, 21, 125; (g) D. Makuc, M. Lenarčič, G.W. Bates, P.A. Gale and J. Plavec, Org. Biomol. Chem. 2009, 7, 3505 ;

12. P.R. Edwards, J.R. Hiscock and P.A. Gale, Tetrahedron. Lett., 2009, 50, 4922.

13. N. R. McElroy and P.C. Jurs, J. Med. Chem., 2003, 46, 1066.

14. T. Mizuno, T. Kino, T.Ito and T. Miyata, Synth. Commun., 2000, 30, 1675 .

15. M.E. Sitzmann and W.H. Gilligan, J. Org. Chem., 1985, 50, 5879 .

16. R. M. Izatt, J.D. Lamb, N.E. Izatt, B.E. Rossiter Jr., J.J. Christensen and B.L. Haymore, J. Am. Chem. Soc., 1979, 101, 6273.

17. F. E. Bordwell, G.E. Drucker and H.E. Fried, J. Org. Chem., 1981, 46, 632.

18. W. Clegg, J. Chem. Soc. Dalton Trans., 2000, 3223. 